Rethinking the origins of homonormativity: the diverse economies of rural gay life in England and Wales in the 1970s and 1980

(Accepted for publication in Transactions of the Institute of British Geographers 1 July 2015)

\author{
Dr Gavin Brown \\ University of Leicester \\ Department of Geography \\ University Road \\ Leicester LE1 7RH, UK \\ Email: gpb10@le.ac.uk
}




\title{
Rethinking the origins of homonormativity: the diverse economies of rural gay life in England and Wales in the 1970s and 1980s
}

\begin{abstract}
This paper rethinks the origins of contemporary homonormativity. Through an analysis of archival material from a rural lesbian and gay social movement from the 1970s, it questions the common link between homonormativity and urban neoliberalism. The Gay Rural Aid \& Information Network (GRAIN) provided support to lesbians and gay men living in rural Britain and/or who were exploring the possibility of leaving the city for rural life. The network consisted of a heterogeneous mix of lesbian and gay environmentalists and 'back-tothe-land' enthusiasts, older lesbians and gay men who had retired to the countryside, and rural-based gay activists. Drawing on archival material relating to GRAIN, this paper traces the diverse economic practices engaged in by rural-based lesbians and gay men in this period. GRAIN members engaged in a complex mix of diverse economic practices and relations, both as a means towards their goal of living more 'sustainably' and in order to fit in to the changing post-productivist rural economy. By acknowledging the ambiguous sexual politics of this counter-cultural social movement, the paper questions theorizations of contemporary homonormativity which locate its origins solely in relation to neoliberal socio-economic relations and subjectivities.
\end{abstract}

Keywords: homonormativity; geographies of sexualities; diverse economies; rural sexualities; cultural and historical geography; England \& Wales 


\section{Introduction}

The 1970s are often celebrated as the decade in which urban lesbian and gay subcultures became (qualitatively more) visible in major cities within the Global North (Abraham 2009). This paper tells a different story. In the late 1970s and early 1980s the Gay Rural Aid \& Information Network (GRAIN) provided support to lesbians and gay men living in rural Britain (or seeking to leave the city for rural life). Drawing on archival material relating to GRAIN (held in the Hall-Carpenter Archives at the London School of Economics) I trace the diverse economic practices engaged in by rural-based lesbians and gay men in Britain at the start of the 1980s. My paper contributes to expanding the field to LGBT history beyond its usual urban perspectives, highlighting how a geographical analysis of rural lesbian and gay lives in the recent past might enrich this rapidly expanding field. By linking this focus to questions of political and economic change, the paper offers a means of refining and critiquing the popular conceptual vocabulary of contemporary queer and sexuality studies.

This paper thinks critically about the origins and uses of the concept of 'homonormativity'. More than a decade ago, Duggan (2002) identified a 'new homonormativity' in the context of increasingly liberal social attitudes to homosexuality, and the enactment of new forms of legal 'equality' in many jurisdictions. Duggan noted that the corporate media was increasingly presenting positive images of lesbian and gay couples in its programming, and mainstream businesses were actively seeking to capitalise on the perceived spending power of gay consumers. In contrast to the 1970 s, when gay people created a visible public culture on the streets of major cities; settled same-sex couples engaged in privatised domestic consumption are becoming socially accepted. Duggan (2002: 179) theorized that these changes were an expression of "the sexual politics of neoliberalism". 
While many of the features that Duggan and others (Richardson 2005; Puar 2006) have ascribed to homonormativity can easily be identified, I believe their apparent power stems from a decidedly metrocentric study of lesbian and gay life. That perspective simultaneously bemoans the neoliberal sexual subjectivities reproduced in major urban centres, whilst also positioning rural lives as backward (to a greater or lesser extent) in relation to them.

In this paper I deliberately look back to a time when neoliberalism was in the ascendency, but its (apparent) hegemony had not yet been realised. In charting the diverse economies engaged in by GRAIN members, my paper complicates geotemporal understandings that present rural homosexualities as invisible and backward compared to urban sexual subcultures. By examining the diverse economies of rural gay life thirty years ago, I am seeking to make visible the diverse economic practices that shape gender and sexual minority lives today in the spaces and practices that exceed simplistic associations with homonormativity. At the same time, I question the extent to which emerging forms of 'homonormativity' were tied to particular forms of urban consumption and ask whether those who sought alternative, rural lives became complicit in articulating a critique of 'hedonistic' urban lifestyles that, in turn, contributed to more conservative sexual politics.

Following this introduction, my paper is structured around four sections. I begin by positioning this study in relation to existing debates about rural sexualities, the development of homonormative social relations, and the diverse economies paradigm proposed by GibsonGraham (2006, 2008). Having scoped a conceptual framework with which to reconsider rural gay life in 1980s' Britain; in the second section, I introduce the work of GRAIN in supporting sexual minorities living in (and moving to) rural areas at that time. The paper's third section examines the diverse economies that the members of GRAIN engaged in, in order to lead the lives they desired in rural Britain. The final section considers how GRAIN members related to urban gay life at the time. This section disrupts popular geotemporal 
descriptions of rural (gay) life as 'backwards'; in contrast, it examines the modes of living that GRAIN members sought in the country, as an alternative to urban gay life. The concluding discussion utilises my analysis of the beliefs and practices of GRAIN members to pose new questions about the origins of contemporary 'homonormativity'; questioning, in particular, if it is sufficient to identify this as 'the sexual politics of neoliberalism' (Duggan 2002).

\section{Understandings of rural gay life and the place of homonormativity}

My analysis of the lives of GRAIN members and the argument I build about their lives sits at the intersection of three bodies of literature - geographical writing on rural gay lives (which I contextualise within broader debates about social, cultural and economic change in rural areas); debates about the emergence of homonormativity; and, the study of diverse economies inspired by Gibson-Graham $(2006 ; 2008)$. Here I address each of these themes in turn to articulate an appropriate framework for interpreting the lives of GRAIN participants in relation to contemporary sexual politics. I argue that this historical engagement with the diverse economies of rural gay life offers new possibilities for understanding the heterogeneous origins of recent 'homonormative' social attitudes and relations.

Much of the early work by geographers interested in the spatialities of sexual minority lives focused on the development and functioning of lesbian and gay spaces in urban settings (Binnie 1995; Knopp 1992); and, even then, primarily focused on major metropolitan centres (Brown 2008). Early attempts to provoke discussion of rural sexualities (Bell and Valentine 1995) gained little traction; but, more recently, geographers have paid increasing attention to such themes (Bell 2003; Little 2003; Phillips et al 2000). This work was undertaken in a context where rural geographers were paying scholarly attention to a wider expressions of 
'rural otherness' (Cloke and Little 1997; Milbourne 1997) in the context of post-productivist changes to agriculture and rural economies (Marsden 1998).

Bell (2003) has contrasted the rural as a site of belonging for sexual minorities with narratives that understand and represent it as a site of alienation. He presents two contrasting conceptualisations - the 'homosexual rural' and the 'rural homosexual'. The former consists of imaginary representations of an Arcadian 'gay idyll' drawing on tropes of erotic natures, rugged masculinity, and innocence. The latter, in contrast, attends to the lived experience of lesbians and gay men in rural areas. Elements of both viewpoints can be found in the literature and correspondence contained in the GRAIN archive and examined in this paper. Shuttleton (2000: 128) notes that the appeal to gay pastoralism originated in the visions of 'comradely love' articulated by gay utopian socialists such as Whitman and Carpenter who, in turn, served as an inspiration for some strands of gay liberation politics in the 1970s. In this gay pastoralist perspective, certain rugged rural masculinities become, through their close connection with the land, idealised and rural landscapes become imbued with homoerotic potential.

In contrast, Bell's (2003) articulation of 'the rural homosexual' attends to the lived experience of gay men living in rural space. Focusing primarily on evidence from the rural Midwest of the USA, he examined how gay men create space in which to meet and support each other in the context of "social and spatial isolation, ambient homophobia, lack of community development, disconnection from 'gay Meccas', [and] religious and political intolerance," (Bell 2003: 186). Nevertheless, he was quick to acknowledge that such spaces are never entirely devoid of gay social networks; it is simply that these are primarily articulated through domestic, rather than public, space. 
Whether it is imagined as an idyll or a backwater, rural space has frequently been presented as being 'backwards' (or old fashioned) in relation to homosexuality. In a North American context, Halberstam (2005) exposed a certain 'metronormativity' that celebrates metropolitan urban centres on the coasts of the United States as progressive centres of lesbian and gay life, while rural central states are deemed to be stuck in the past in terms of their social attitudes towards (and social infrastructures for) sexual minorities.

In examining rural homosexualities, Gorman-Murray and his co-editors (2012) identify three overlapping narratives of (im)mobility in the literature: rural-urban migration (frequently understood as a search for supportive 'community' and narrated as part of coming out narratives); urban-rural migration (often, but not exclusively, tied to back-to-the-land or earth-based spiritual movements); and, finally, tales of staying put and making do. Since at least the 1970s, the assumption has been that rural-born lesbians and gay men migrate to major cities with visible lesbian and gay communities, in order to avoid social stigma, reinvent themselves and lead openly gay lives (Weston 1995). Work from both the United States and Australia has complicated these overly simplistic migration patterns, acknowledging that lesbians and gay men who were born in rural areas can be more peripatetic, moving to other locations than major urban centres (including small rural towns), and some return to live in rural areas at different points in their lives (Knopp and Brown 2003; Gorman-Murray 2007, 2009).

Scholarly work on those lesbians and gay men who choose to make a life for themselves in rural areas has also drawn attention to the experiences of those sexual minorities who engage in urban-rural migrations. Some of this is return migration by rural-born lesbians and gay men, but other trends have been noted too, as different groups of lesbians and gay men have actively sought to create an alternative to urban-based sexual cultures. In this regard, geographers have studied various attempts to establish separatist, 'women's land' either in 
the form of permanent intentional communities (Valentine 1997; Sandilands 2002), or more temporary festival sites (Browne 2011). These rural women-only spaces attempt to construct an alternative to male-dominated, heteropatriarchal urban cultures, and have often been associated with eco-feminist beliefs within the broader back-to-the-land movements. As part of broader counter-cultural and counter-urban flows (Halfacree 2006), since the 1970s, groups of gay and bisexual men, have also experimented with rural communal life as an alternative to what they perceived as the alienated, objectified sexual cultures of expanding urban gay subcultures (Hennen 2004; Morgensen 2009). Despite the counter-cultural, antiurban critique (Herring 2010) that initially inspired many of these experiments in lesbian and gay rural living, they do not exist in isolation from urban lesbian and gay cultures.

Frequently, these experimental communities exist in proximity to small rural towns that have become known, over time, as gay-friendly places to live or as holiday destinations that offer many of the features of urban gay life in a rural or coastal setting (Gorman-Murray, Waitt and Gibson 2012; Smith and Holt 2005).

Herring (2010) identified two forms of 'anti-urbanism' associated with contemporary debates about sexual politics in the United States. The first aligns closely with the homonormative politics I shall discuss shortly. It calls for the 'deghettoization' and 'deurbanization' of gay life, and encourages lesbians and gay men to adapt to the values of suburban and small town America (Herring 2010: 11). It is a plea for the privatization and domestication of gay life, and positions itself in contrast to the public sexual cultures of urban gay neighbourhoods. The second form of 'queer anti-urbanism' that Herring (2010: 12 - 13) identifies is more critical and, he believes, has the potential to disrupt, question and subvert metronormative assumptions about the gay absence from (and persecution in) rural space. It is an antiurbanism not only in the spirit of lesbian separatist communes and radical faerie gatherings, but also the everyday lives of those rural sexual minorities who choose to stay put and thrive 
in small towns and rural locations. Although Herring's work offers a largely sympathetic exploration of 'queer anti-urbanism' in the United States, he offers some words of caution: first, to resist (re)producing too rigid a rural/urban binary; second, to avoid replacing metronormative gay life with a presentation of "the rural as more authentic" (2010:26); third, to recognise that neither urban nor rural areas are uniform or uncomplicated. For me, there are similarities between the outlook and practices of GRAIN and the forms of queer antiurbanism studied by Herring. However, as I shall articulate later in the paper, I believe it is too simplistic to dichotomize their critical anti-urbanism from more conservative critiques of gay urban cultures.

In the last two decades, social attitudes about homosexuality have liberalised significantly and there have been rapid shifts towards formal legal equality for lesbians and gay men in many countries (Weeks 2007). Although uneven, these changes have been witnessed, in different permutations, in most of the Global North and several of the more dynamic emerging economies in the Global South. The impacts and consequences of these social changes have been uneven and inconsistent. The lives of many lesbians and gay men have been improved by increased social tolerance and legal 'equality'; but, these gains have not been enjoyed universally. There remain fears that these new 'rights' have strengthened the relative privilege of affluent white, gay professionals. The boundaries of the socially acceptable have shifted, as sexual minorities increasingly seek to demonstrate their 'sameness' with heterosexual social norms (Richardson 2005). In the era of same-sex marriage, gay life has been domesticated. The politics of contemporary austerity look favourably on stable romantic couples with the capability and resources to secure each other's welfare without recourse to state benefits. When considering Duggan's (2002: 179) definition of 'the new homonormativity' as an expression of the sexual politics of neoliberalism, it is important to consider neoliberalism not only as an economic theory, but a 
form of governmentality that promotes personal responsibility and individualised autonomy in the context of marketized 'free choice' (Weiss, 2011: 18). The empirical material presented here begins to complicate this understanding of homonormativity. An examination of the lives of GRAIN members' lives nearly forty years ago suggests that aspects of 'homonormative' values can be found much earlier than is commonly thought and within socio-political projects that positioned themselves as alternatives to the emerging neoliberal politics of the period.

The world in which the members of GRAIN lived was very different: in the UK, the age of consent for gay men was still higher than for heterosexuals; there were no statutory protections against discrimination on the basis of sexuality; and, same-sex relationships had no legal recognition. Throughout the 1980s, the percentage of British adults expressing the belief that homosexuality was wrong actually increased; although, there was a significant generational difference and, by the end of the decade half of people aged under 25 were accepting of homosexuality (Weeks 2007: 17 -18). In Duggan's (2002) articulation of the 'new homonormativity', the term 'new' is crucial and implies two key points: first, that the phenomenon she was describing was historically specific to the start of the new millennium; and, second, that it was distinct from other potentially normative expressions of homosexuality that might have existed in earlier periods.

One of the aims of this paper is to consider how the kernels of the new homonormativity were sown in the period when neoliberalism was still in the ascendancy. I argue that it is important to rethink the link between homonormativity and neoliberalism for two reasons: first, to show that 'homonormativity' did not arise, ready formed, once neoliberal politics were firmly entrenched; and, second, to suggest that the social norms attributed to homonormativity are complex and multiple, without a single point of origin or form of expression. As I have previously argued (Brown 2009), there are dangers in seeing 
neoliberalism and, therefore, homonormativity as all-encompassing. Theorizations that see expressions of neoliberalism and homonormativity everywhere, in everything, preclude other experiences, economic practices, and social relationships. As I have argued more recently (Brown 2012), such theorizations of homonormativity frequently overlook geographical variation and specificity in the lived experience of sexual minorities and (re)centre exactly the metropolitan experiences that they critique (cf Podmore 2013).

By focusing on rural gay lives, this paper offers a counterpoint to the urban focus of debates about homonormativity. Although it seems likely that GRAIN members would have contested this at the time, their back-to-the-land experiments were part of broader changes in the British countryside brought about, in part, by the imposition of new neoliberal policies (Halfacree 2006, 2007). Despite the critiques (Evans et al 2002) of how it quickly became 'the new orthodoxy', the debates about the social, cultural and economic consequences of 'post-productivism' (Marsden 1998; Milbourne 1997) were an attempt to theorize the impact of neoliberalism on British rural spaces. Building on my earlier work (Brown 2009; 2012), this paper engages with the work of Gibson-Graham $(2006 ; 2008)$ and their collaborators (Gibson-Graham et al 2013) to explore the potential for understanding the diverse economies of rural gay lives. Gibson-Graham's project attempts to expand and diversify the vocabulary of economic processes, in order to unsettle the dominant ways of discussing contemporary economics, which tend to assert the singularity of 'the (capitalist) economy'. I use an engagement with their work (and the diverse economic practices of GRAIN members) to argue that although contemporary homonormativity may be consequent to urban neoliberalism, its emergence can also be found in other spaces and in more diverse forms, including rural sites that were shaped by economic relations that were other than obviously 'neoliberal'. 
Inspired by queer and postcolonial thinking, Gibson-Graham reads economic relations 'for difference'. They describe a diverse economy in which, alongside the components of the 'mainstream economy', there are a wide spectrum of other economic transactions, enterprises, and relations that "sustain material survival and well-being" (Gibson-Graham, 2005: 12). In their most recent work (Gibson-Graham et al 2013) this inventory is expanded to consider diverse forms of property and finance. For them, it is possible to understand capitalism as coexisting with a positive multiplicity of other economic forms (GibsonGraham, 1996: 141 - 143). Their approach draws attention to the local trading systems, forms of barter, and alternative currencies that exist within and alongside those economic transactions more commonly associated with mainstream markets (Gibson-Graham 2006: 71). Similarly, they acknowledge the many forms of unwaged work that occur within the household; the continuing role of self-provisioned goods, and numerous types of communal production and shared assets. An important aspect of Gibson-Graham's (2006) political project is to explore how making diverse economies visible might aid struggles to become different kinds of economic subjects. Many critics of Gibson-Graham's approach (Fuller and Jonas 2003; Gritzas and Kavoulakos 2015; Lee 2010) argue that their focus on 'diversity' weakens their commitment to fostering anti-capitalist alternative economies. In some ways, the empirical example of GRAIN turns this critique back on itself, showing how easily practices that were understood subjectively as 'alternatives' can remain either just outside the mainstream or become reassimilated into it.

GRAIN members engaged in diverse economic practices and relations as they sought to construct liveable alternatives to urban gay life. In examining their efforts, this paper expands the study of rural homosexualities, bringing the geography of sexualities into further dialogue with heterodox debates in economic geography. The paper contributes to debates in the wider social sciences that critique the metronormative assumptions that underpin so many critical 
studies of (homo)sexuality. Historically, the empirical material on which the paper is based is situated before the emergence of 'the new homonormativity'; however, this work engages with debates surrounding homonormativity, to consider how earlier expressions of 'critical queer anti-urbanism' may themselves have anticipated later more conservative questioning of gay urban life. One of the major contributions of this paper, then, is a challenge to overly simplistic identifications of homonormativity with mainstream urban gay life rooted in neoliberal subjectivities and particular regimes of capitalist consumption.

\section{GRAIN: Gay Rural Aid \& Information Network}

The GRAIN network consisted of a heterogeneous mix of lesbian and gay environmentalists and 'back-to-the-land' enthusiasts, older lesbians and gay men who had retired to the countryside, and rural-based gay activists. These diverse constituencies often experienced rural life in contrasting ways, finding different means of engaging with local economies and social networks, and hotly debating what it meant to be gay in rural Britain. It is clear that although many of GRAIN's correspondents felt an affinity with the (largely metropolitanbased) radical, counter-cultural strands of gay politics and culture at the time, the network also cooperated with local groups of the Campaign for Homosexual Equality which (in both attitudes and location) has often been consider as more provincial (Robinson 2007). These multiple connections position GRAIN at the intersection of competing visions of emerging 'homonormativities'.

A selection of papers relating to GRAIN is held in the Hall-Carpenter Archives at the London School of Economics. These do not represent the 'official' archive of the network. Rather, it is likely that they were deposited along with other papers by an individual GRAIN member. The Hall-Carpenter was started by community volunteers in 1980 . The documents in its 
collection were transferred to the LSE some time later. Due to the amateur origins of the archive, the origins and provenance of deposits are not always fully known. The materials related to GRAIN are contained in one main archival box and a further folder. They consist of an (incomplete) selection of the group's newsletter from 1977 until 1986. In conducting this research, I was able to read all relevant items in the archive, along with material about several of the other contemporaneous counter-cultural gay organisations (such as the Wild Lavender Housing Cooperative) mentioned in the newsletters. The archive also contains a small set of papers from 1986 produced by a group called the Gay Men's Rural Project which appears to have briefly superseded GRAIN, diverting the efforts of some of the network's more active members. I made some attempt to trace surviving members of GRAIN with a view to interviewing them about the origins and activities of the network. Although I was able to trace one former member (with some degree of certainty), they did not return my messages and no interview has taken place. That work remains to be done.

When the group was established in 1976, it adopted the following aims:

a) To form a network of gay people interested in self-sufficiency or similar subjects e.g. organic agriculture etc. $[\ldots]$

c) That it should get itself together as a group before joining with the 'straight' selfsufficiency network

d) That so doing, it can combat (from a STRONG position) the sexist (male heterosexual dominated) nature of the self-sufficiency movement as it presently exists 
e) That it should exist primarily for moral support of gay people working in this 'hostile' environment and so try to overcome the oppression of women on the one hand and all gays in the other in this field...

f) That it should also exist for the bartering of produce (e.g. in agriculture and crafts)

g) That it should exist as a 'help and share' scheme - e.g. helping each other at harvest, sharing a working horse and implements etc. ${ }^{\mathrm{i}}$

This was a self-organised lesbian and gay social movement that sought some degree of autonomy from the heteronormative practices and assumptions of the wider back-to-the-land social movement with which it was associated (Halfacree 2006, 2007). Even sympathetic commentators on the counterculture of the 1960s and 1970s acknowledge its pervasive sexism and heteronormativity (Rowbotham 2000; Robinson 2007), so the need for a group like GRAIN must be understood in this context. The language used in GRAIN's aims and objectives offers an insight into the diverse economies at work within the network and the lives of its members - the aims make reference to self-sufficiency, barter, helping and sharing.

Because one of the aims of the network was to put rural lesbians and gays in touch with each other (in a world before internet social network sites), each issue of the GRAIN newsletter contained the names and addresses of members (and often a short description of their motivation for living in the country, details of how they made a living, as well as specific requests for information and advice). From the archived records I have accessed, the network's members appear to have been concentrated in the west of Wales (Dyfed) and the West Country (various locations in Devon and Somerset), with others also living in Sussex and East Anglia. This suggests some synergies with the distribution of broader 'back-to-theland' experiments at the time (Halfacree 2006). Some of the network's members moved to 
areas of the 'contested countryside' (Marsden 1998), where they competed for space with second home owners in the emerging post-productivist rural economy (Halfacree 2012). However, others appear to have bought properties in those remote rural areas where farming and local economies were reliant on state subsidy, resulting in more 'clientistic' relations (Marsden 1998)

Although GRAIN had clear, if extensive, aims, the pages of its newsletter indicate that their membership often had conflicting expectations of what they wanted from the network. A core of the group were ideologically committed to rural self-sufficiency and looked to others in the network to share practical advice about how to realise this. For them attempting to foster selfsufficiency was a necessary response to environmental and economic crisis.

"What does [seem] clear is that the need for GRAIN is still as valid now as it was in those early days, and who knows the need for GRAIN may even be greater in the future, for the society in which we live at this time is having to change at a very much faster pace than it has in the past; unemployment is going up and up, costs are doing likewise, the future is uncertain for many and new ways to live are going to have to be found. Some people are going to have to move away from the area they now live in, others will have to learn how to be more self-sufficient in their lives. We will all have to change in some way or the other." ii

Interwoven with the practical discussions of self-sufficiency and sustainable rural life, are expressions of what Herring (2010), in a US context, has termed "queer anti-urbanism". There were adverts for the American rural queer magazines RFD (that became Radical Faerie Digest) and Country Women, along with advice on where to buy them in London, in the December 1977 edition of the GRAIN newsletter (cf Herring 2010). This suggests that GRAIN was networked with rural lesbians and gay men internationally. In the newsletters 
from the early 1980 s, the references to wider networks of alternative, counter-cultural and communal rural lifestyle movements in the UK gathered pace - there was a report from the Edward Carpenter Community's gay men's (spiritual) retreat at Lauristen Hall (Issue 26), and contention in the subsequent newsletter that the lesbian retreat there had not also been mentioned. Similarly, issue 27 contained adverts for the Alternative Communities Movement and a report on trip to the Centre for Alternative Technology.

In addition to this commitment to self-sufficiency and queer anti-urbanism, GRAIN's members (particularly the men) were seeking connection and a means of overcoming the isolation caused by the friction of distance from other gay people and gay-oriented services. This tendency was sometimes contested by those who were most ideologically committed to the group's environmental ethics.

"Judging by the communications that I have received from other GRAIN members it is hardly more than a 'postal cottaging' service. Surely there is more to it than that, I enjoy sex but I looked to GRAIN for something deeper."

Periodically, the network were challenged to look beyond their own needs and experiences (as mostly former city-dwellers who had relocated to the country, or aspired to do so) and to consider how they could broaden their remit to meet the needs of other gender and sexual minority people living in rural locations. A letter from Richard Webster in Penrith (who had been the convenor of the Cumbrian \& Borders Campaign for Homosexual Equality a few years earlier) was published in issue 30 of the GRAIN newsletter. It makes this point very forcefully and deserves quoting at length:

"There does seem an element of self-satisfied elitism in the self-sufficiency movement (but you've worked hard enough to attain it, haven't you?) and then, as a result of that crazy membership questionnaire which ought to be revamped, I read of 
people who had settled in their 'chosen area' or want to move to one, I always want to ask whether the area has chosen them.

"I'm serious. Country dwellers, particularly in remote parts of Britain, have to endure a lot (admittedly I'm writing in the middle of the holiday season) but I suspect that you who are happily developing your alternative life-styles have more to offer to the rural community than have, for instance, retired middle-class urbanites and second homers. I only wish there were more signs of some awareness that, when you move from the cities, you move into someone else's culture and often into societies whose very identity is threatened by pressures from outside of which potentially you are one."iv

While the network's broad aims served to hold the different constituencies within its membership together; classed, gendered, and ideological differences continued to be played out in the pages of the group's newsletter. Although many within the network articulated seemingly progressive ecological and social motivations for moving to rural areas; at times, their queer anti-urbanism betrayed more conservative sexual politics. Before exploring this tension further, I examine the heterogeneous ways in which GRAIN members made a living in rural Britain, and consider the diverse economies that sustained them.

\section{Diverse economies of rural gay lives}

Homonormativity, as it has been theorised over recent years, tends to be associated with neoliberal economic practices (and forms of governmentality). In this paper, however, I examine the emerging 'homonorms' associated with the diverse economic practices and relationships engaged in by members of the GRAIN network. They were engaged in a 
complex mix of wage labour, self-employment, self-provisioning, non-monetary exchange and communal practices that were embedded in their local communities to varying degrees; and, I am more interested in the 'diversity' of these economic practices than their 'alterity' (Lee 2010). I find it useful to approach homonormativity not as a single entity, but as a cluster of different traits and phenomena (including: the prioritisation of coupledom and domestic economies; a rejection of public sexual cultures; preference for modest personal pleasures over collective hedonism; and a desire to 'fit in' to heterosexual society). Not all of these elements need to be clustered together and aligned for gay-specific social norms to emerge and operate. By examining the 'homonorms' that emerge through the diverse economic practices of GRAIN members, I suggest that homonormativities pre-date contemporary neoliberalism and are multiple, as well as time and place specific.

The membership listings contained in the GRAIN newsletter offer some clues as to the forms of labour and employment engaged in by the network's membership. One member, living in Somerset, described themselves as being involved in "hotel keeping, gardening, [and] carpentry" . Neville ${ }^{\mathrm{vi}}$ described that he "works as a jobbing gardener," and was "hoping to have enough time to cultivate own garden and entertain". The implication of the description 'jobbing', is that he had chosen not to work full-time, took occasional work when he could, and was seeking to balance his time between some paid work and time for cultivating his own garden. This desire for a life not dominated by waged labour, although financially frugal, might be understood as a form of voluntary simplicity or 'alternative hedonism' (Soper 2008).

One of the intriguing descriptions comes from Paul:

"I am 23 years old and after spending most of my life in the English Midlands have recently moved to Wrexham, as 'housekeeper' to Graham and Clive.”vii 
The inverted commas around housekeeper is ripe for a queer reading - there is, perhaps, an implication that this young man is a 'kept boy' for an older couple (Scott 2003). The range of his domestic duties is left to the imagination. But in terms of thinking about diverse economic practices his role certainly broadens the scope of the work engaged in by GRAIN members beyond straightforward waged labour..

But the most complete discussion of how GRAIN members utilized diverse economic practices in order to make gay life work in the country comes from the following article from the network's January/February 1983 newsletter:

"So, having found that place in the country, how do you manage to stay there; how do you become financially viable? ... [U]nless you are prepared to have a constant running battle with the Social Security, do try and make it on your own, it's a lot more peaceful in the long run. ... Self-sufficiency is just not possible without some form of cash flow. ... Having people stay is not an easy way to make money. It demands that you have as comfortable a home as you can get together, the food that you offer is most important - people on holiday are always hungry, and meals have to be served on time - the house must be kept cleaner than maybe one would do if living alone. All these things sound obvious, but one is charging money, and so a service is demanded. And don't forget all this is on top of all the other work that has to be done about the place - if you have animals the days can be long and demanding. [...]

Our bread-and-butter money comes from David going out to work two days a week at the local hair salon. He could do more days, but we do not want to slip back into the old routine of five days, 9 to $5 .[\ldots]$

Selling at the 'gate' can be a good idea if your house gets enough passing traffic. We've sold eggs, pate, flans, pies and goats' cheese, but we don't get enough traffic 
to make it worthwhile doing all the time - it's not only the visitors that you can sell to, local people don't do nearly as much baking themselves these days. It's easier to buy it all done."viii

It is useful to take a moment to inventory the diverse economic practices and relations engaged in by David and his (unnamed) partner. They reject relying on state welfare benefits due to the "constant running battle[s]" they entail; choosing a "more peaceful life" instead. While their goal is self-sufficiency, they acknowledge that this requires "some form of cash flow" to finance it. They open their house to paying guests, running a bed and breakfast business, but recognise that there are costs, in terms of time and labour, associated with this enterprise that threaten to take them away from their core commitment to running the smallholding and tending their animals. In reality, these duties cannot be overlooked and so their working hours are increased during the holiday season. To provide a regular income for their everyday needs, David engages in paid labour, off the farm, as a hairdresser; but they resist the temptation to for him to work full-time in order to maximise and regularise their income. Instead they sell fresh produce from the smallholding, along with baked goods, at their gate to both local residents and passing tourists. In addition to these multiple forms of labour and enterprise, Geoffrey Leigh outlined how he and his partner had relied on various forms of barter, sharing and gift economies since establishing their smallholding in Norfolk three years previously:

"All I can say is that ever since we (two gay men) moved here nearly three years ago, we have been shown the most friendly people that we could wish to meet: good neighbours who all feed the animals if we can't make it back in time for the afternoon feed; helpful local small farmers who baled our hay for $5 \mathrm{p}$ a bale, lent us a ram; and local villagers always willing to give helpful advice (only) when requested."ix 
Very often in the pages of the GRAIN newsletter, the market transactions of the growing urban commercial gay bar scene were contrasted with the local trading systems, skill-swaps and forms of barter that GRAIN's members utilised in their rural lives. In the quotes above, the non-market transactions found in household (economic) flows and gift economies are frequently given more prominence than mainstream, capitalist market transactions. I do not think that these diverse economic practices shaped GRAIN members' emerging homonormative values in a deterministic sense, but they did probably help them fit in (as lesbians and gay men) into the changing, post-productivist landscape of rural England and Wales (Halfacree 2006), placing them in comfortable proximity to the lives of other incomers and more established rural residents (Miller 2010). For GRAIN members, it appears that their engagement in diverse economic practices and relationships was entangled with a 'reframing' (Gritzas and Kavoulakkos 2015: 15) of their lives, through which they reimagined what (and where) it meant to be gay in that period. Like the wider 'back-to-the-land' movement of the period, they worked through the tensions between an anti-urban impulse towards land work and self-sufficiency with a desire for connections in the places where they lived. Diverse economies made rural gay lives possible and more ordinary. By acknowledging and engaging with the already existing diverse economies around them, lesbian and gay lives became embedded in rural areas - to do otherwise would have made them stand out ${ }^{\mathrm{x}}$.

Although some GRAIN members were involved in some form of regular waged labour, they wrote frequently of their commitments to reducing the amount of time they worked in waged labour for others, choosing to work part-time as much as possible. Many were self-employed (as carpenters and jobbing gardeners, for example) seeking more control over the hours they worked. Frequently, unpaid domestic work, self-provisioning, and volunteer labour were mentioned prominently alongside waged labour. 
A consideration of the types of enterprises mentioned by GRAIN members reveals that very few straight-forwardly capitalist enterprises are listed in their writings. Certainly, some of the members ran independent businesses (like bed and breakfasts), but more frequently the GRAIN newsletters make reference to 'alternative capitalist' enterprises with a social ethic or enterprises that were run on a not-for-profit basis - housing co-ops, the Centre for Alternative Technology or small scale, informal enterprises run from their homes (such as David and his partner selling produce at their gate). Alongside these, communal enterprises are also

mentioned - large rural houses run as communes, the gatherings called by the Edward Carpenter Community, and the queerly communal space of the 'cottage' (a public toilet used for public homosex) (Brown 2009).

Gibson-Graham (2006) conceived of their diverse economies matrix as a performative device to make non-capitalist economic relations visible. In the correspondence produced by GRAIN, diverse economic practices, forms of labour and enterprises are not only visible, they are a positive multiplicity. The nature of the socio-political project that most GRAIN members were engaged in makes their diverse economic practices particularly visible in the archival record. Recent research suggests their experiences were not exceptional (WynneJones 2014). I now turn to an examination of how GRAIN members experienced life, as visible members of sexual minorities, in rural Britain in the 1970s and ' 80 s.

\section{Relating to rural life}

In charting the diverse economies engaged in by GRAIN members, this paper complicates geotemporal understandings that present rural homosexualities as invisible and backward compared to urban sexual subcultures. Certainly there are times in the newsletters where 
members appeal for urban (and mostly London-based) supporters to share news with them of gay politics and culture.

"If anyone lives in London and has access to gay information, meetings etc. would [they] care to do a page every two months?"xi

To some extent, then, their interest in gay life still remains orientated towards urban and metropolitan spaces. In this section, I examine three narratives emerging from the pages of the GRAIN newsletter, which suggest the complex experiences of these sexual minority men and women in relation to urban and rural space. First, there are those who recount problems with the 'backwardness' of social attitudes towards sexual difference in rural communities. Second, are a group of people who appeared to be escaping social relations that they found problematic in urban life, but who still wished to retain some connections with urban gay subcultures. Finally, there are narratives of how gay men (frequently couples) had managed to 'fit in' to the rural communities they had moved to. Overall, the members of GRAIN seem to have found ways of making lesbian and gay life work for them in the country - usually as a conscious rejection of what they saw as the unsatisfactory modes of gay life developing in metropolitan centres at the end of the 1970s.

Although not great in number, the pages of the GRAIN newsletter contain some painful stories of violent harassment experienced by lesbians and gay men in rural Britain. One of the most harrowing of these tales is outlined in an extended set of correspondence, published over several issues of the newsletter in the early 1980s, from a retired gay man living with his transsexual lover in a small village in the West Country.

"We are getting quite a lot of harassment where we are living again, window banging and cat calling because of what we are, we do not say or have anything to do with other people, all we want to do with live in peace, most of the folk who live near us 
have accepted us and several have said why don't they leave you alone, you don't interfere with anyone. ... I shall be 70 next birthday and to have all this harassment at my age is really too much, I have not done anything wrong, I can't help it if I am Gay." xii

As this letter explains, this couple sought a 'quiet' life in the country. Although the author suggests they have been accepted by many of their neighbours, the letter also speaks of a relatively isolated and insular existence, punctuated by repeated harassment. Apparently helpful and supportive neighbours suggest that the couple should move out of the village and seek a safer place to live. Ultimately, the couple did move, and found a more supportive place to live openly, safely and undisturbed - not in a big city, but in a slightly larger market town in the region. In the summer of 1986, he provided this update on their circumstances,

"We have been living in this flat for 12 months now, I feel much better, the neighbours are very friendly towards us, I have put on weight where I was 5 stone when I was in the shire, I am now 10 stone. Quite different, isn't it?"xiii

Ensconced in their new flat, Charles Symons had by then found the energy to play an active role in fostering gay social networks in the county. In the same letter, he reported that he was involved in helping to establish a North Devon gay group operating out of the Quaker Meeting House in his town.

The resolution of this story is suggestive of the second theme emerging from the pages of the network's newsletters - those men (and women) who actively chose rural life, but bemoaned the lack of lesbian and gay social networks they found there (and the problematic attitudes they found not just amongst long-term rural residents, but also the wider 'alternative', backto-the-land movement). This second theme is exemplified further by correspondence from 
Peter Graham in 1977. He recounts how his growing disillusionment with the London alternative 'scene' and a chance encounter led him to move to an ashram in North Devon.

"I soon realised I would have to swallow what little was left of my 'gay pride' and leave gay chauvinism and the sexist struggle behind in the city; it was a question of survival, otherwise I would have found myself with no friends at all." xiv

However, he encountered prejudice at the ashram and discovered that some of the older heterosexual men there were offering alternative therapies designed to 'cure' homosexuality.

"So after a year I returned to London, simply because I still need[ed] to be close to other gay people, I don't like the city but it doesn't cause the same degree of anxiety in me that it did before, perhaps because now I know why I'm here, even though I'm very disillusioned with the gay scene generally." xv

Peter's story here is reminiscent of the circulations between rural and urban space that Knopp (2004) noted amongst gay men in the USA. A few years later, a letter from Martin Hodge tells a very similar tale of disillusionment with the urban gay scene, but also discomfort with 'alternative' rural experiments. He too was residing in Devon, as the only gay man living on a commune there. He noted,

"I am keen to see GRAIN continue because I feel a need to make contact with other gay people who live in rural areas and who seek more from life than is promoted within the commercial city-based 'gay scene"' xvi

That search for 'more from life' than the metropolitan gay scene could offer (him), led Martin to choose a communal life in Devon. Although this 'queer anti-urbanism' (Herring 2010) could be interpreted as a socially and sexually conservative rejection of the urban gay scene, the projects and lifestyles that attracted these gay men might also be understood as 
experiments in 'alternative hedonisms' (Soper 2008) that were not simply ascetic or puritanical, even as they sought to reframe pleasure around less materialistic values. Nevertheless, Martin implied that there were limits for him in being the only gay man participating in that particular collective. He sought connections with likeminded gay men through GRAIN and the Edward Carpenter Community. But he was exploring setting up a gay men's rural commune as a means of sharing his counter-cultural ideals without losing connections with other gay men. The experiences of Peter and Martin contrast with the following commentary by Graham in a 1983 issue of the newsletter. He suggested that the original aims of the network in terms of its relationship to the straight self-sufficiency movement, by then, "seem[ed] superfluous - time seems to have lowered these barriers to a great extent"xvii . Clearly such claims were contested within the GRAIN network, but they challenge contemporary assumptions about the 1980s as a period of universal, unremitting prejudice against lesbians and gay men.

Around the same time in the early 1980s, other members of the network began to offer optimistic narratives of how they had been accepted into the rural areas they had adopted. Here Geoffrey tells the story of the move he and his partner made from London to rural Norfolk

"I can recognise similar hopes, fears, feelings etc. as part of our experiences of moving out of London into the rural 'backwater' of Norfolk, as those expressed in the various articles [in the previous newsletter]. ... The only thing I didn't recognise was the hostility/antipathy that Di wrote about. Perhaps rural Norfolk is friendlier than Wales? [...]

Our biggest bonus has been in joining a local small holders' group - here we can meet other people with similar problems and equipment to buy/sell, information to 
exchange, and at the bi-monthly meetings join discussion groups on various topics, which usually adds to our knowledge and interest. Now, whether the issue of our being gay has been talked about by others in the smallholders' group or around the village, I don't know. I am sure that a hell of a lot depends upon you as a person and your willingness to listen and not parade a kind of urban superiority over the 'yokels'! (Unfortunately, we detect this attitude in quite a number of people who have moved into Norfolk from London)."xviii

While he alludes to the perception of rural Norfolk as 'backwards' - a 'backwater' - he asserts that it is crucial to overcome such assumptions in order to make the move from the metropolis successfully. The problem, he suggests, is less the backwardness of rural inhabitants, than the air of superiority to them conveyed by many migrants from urban areas. Incomers need to demonstrate that they are willing to learn from those who have been living in rural areas for a longer time. Geoffrey also suggests that the overlapping social infrastructures of established farming communities and more recent small-holders inspired by a commitment to self-reliance and sustainability were crucial to his household finding their feet in rural Norfolk. In this respect, it is important to remember that GRAIN members were moving not to a static countryside, but to rural spaces which were undergoing significant and complex social and economic changes (Marsden 1998). By engaging with the diverse economic practices of skill-sharing, barter and mutual aid, they found themselves accepted into these changing local communities. In doing so, they were not necessarily engaged in an exceptional set of practices and relations for newcomers who wanted to make connections in their new localities (Jones 1997). On this point, it seems useful to return to the admonishment of the GRAIN network by Richard Webster from Cumbria that I quoted earlier.

“GRAIN should have started moving towards embracing rural gays (as I hope that some of you do on an individual basis) as well as catering for the more self-aware 
incomers whom I take most of you to be. No need to worry about being swamped by yokels. There are still a lot of very timid, lonely and rather frightened people out there. Gay groups and the Gay movement generally have done little for them. The unspoken advice, sometimes even uttered, is 'Why don't you move to London' (or Manchester or wherever)? - a gay equivalent of 'get on your bike' perhaps? Yes, I am angry that little is done to help rural gays. Some of them might even welcome what one of your (obviously male orientated) correspondents referred to snidely as a postal cottaging service.” xix

What is notable here, is Webster's comparison of the advice that gay men should head to major cities for support, with (the Conservative politician) Norman Tebbitt's advice to the unemployed at the time that they should 'get on [their] bike' and look for work. For Webster, it seems, gay urban migration was a conservative option, compared to making rural gay life bearable with fewer material and symbolic resources. There were undoubtedly complex intersections of class, normative gender performance and cultural capital at play in the relative success or failure of the life projects pursued by members of GRAIN. Some, like Martin Hodge, led counter-cultural lives that may have placed them in an uneasy relationship to some of their neighbours, regardless of their sexuality. Others seem to have been the second-homers that Richard Webster railed against. But others still seem to have got on with the hard work of integrating themselves into the web of reciprocal favours sustaining rural life.

\section{Concluding observations}

The Gay Rural Aid and Information Network was created nearly forty years ago, bringing together lesbians and gay men who wanted to live self-sufficient lives in rural areas of 
England and Wales. This paper has drawn on back issues of GRAIN's newsletters and other archived material to re-examine aspects of rural lesbian and gay life in Britain in the 1970s and 1980s. Specifically, I have utilized Gibson-Graham's (2006) diverse economies approach to think about the multiple ways in which members of GRAIN made rural gay life liveable and sustainable. Many members relied on small-scale domestic craft production, a portfolio of part-time employment, volunteer and domestic labour, as well as self-provisioning as means of achieving a sustainable gay life in the country. This attention to the diversity of economic practices and relations that sustained GRAIN members adds new complexity to contemporary histories of rural gay life in the late twentieth century (and hints at new questions to be posed about the geographies of such lives in the present).

This engagement with the diverse economies of rural gay life in the recent past opens new avenues for considering the heterogeneous origins of contemporary 'homonormative' social relations. Following Duggan (2002), most theorizations of the increasing social acceptance of homosexuality and the acceleration of formal legal equality for lesbians and gay men understand homonormativity as an expression of the sexual politics of neoliberalism. The empirical material presented in this paper begins to complicate this conceptualisation. An examination of the lives of GRAIN members suggests that aspects of 'homonormative' values can be found much earlier than is commonly thought, in a period when neoliberalism was in the ascendancy, and amongst a social group that believed they were enacting an alternative to the dominant politics of the Thatcher era.

Although Thatcher came to power midway through GRAIN's existence, and began to implement neoliberal policies in Britain, the sexual politics of the period were a lot less liberal than today. A key contribution of this paper is to rethink the link between homonormativity and neoliberalism, suggesting that aspects of 'homonormativity' predate the consolidation of contemporary neoliberalism. I question whether it is sufficient to identify 
homonormativity as originating solely out of neoliberal social relations (that are most easily identified in urban space). Just as I think it is problematic to over-associate urban gay life with the homonormative sexual politics of neoliberalism; I also believe it is over-simplistic to assume that the more diverse economic practices of rural lesbians and gay men committed to more 'sustainable' lives are (or were) any less conservative in their sexual politics. GRAIN members' search for an alternative to the urban gay scene of the 1970s was always ambiguous in its sexual (as well as class and racial) politics: in articulating their desire for more frugal and sustainable ways of living, they often presented urban gay life as unproductive, unsustainable and hedonistic. I question whether their counter-cultural, environmentally-friendly retreat from public gay life in the city might also represent a search for new forms of productivity, self-reliance and domestication that were not unambiguously progressive.

While I believe that an attention to diverse economic practices can add complexity and nuance to studies of rural gay life, it is also vital to acknowledge the contradictory intersections of sexual politics with (advocates of) diverse economic practices. Adding a historical geographical perspective to these debates can offer a better understanding of how (and where) those contradictions play out over time. By bringing a wider range of economic practices into view, scholars can develop the capacity to see lives shaped by more than just neoliberalism. Thinking about the diversity of economic practices and social relations that might be associated with emerging homonormative attitudes emphasizes that 'homonormativity' is not as a single entity, but a cluster of traits, relationships and values. A geography of homonormativity must appreciate that homonormativities are multiple, as well as time and place specific. 


\section{Acknowledgements}

I would like to thank the staff at the Hall-Carpenter Archives at the London School of Economics for their assistance. The initial archival research was conducted during a sabbatical granted to me by the University of Leicester. Earlier versions of this paper were presented at the Royal Geographical Society Annual Conference in Edinburgh in 2012, at seminars at the University of Leicester and Brunel University, and at a conference jointly organised by students from Falmouth University and the University of Exeter at Penryn. I thank these various audiences for their comments and questions. Kathy Gibson, Kath Browne, Peter Kraftl, Cesare di Feliciantonio and Joseph De Lappe have all given valuable feedback on the work as it has developed and provoked new ways of thinking about the material. Finally I thank Gavin Bridge and the three anonymous reviewers for their constructive engagements with the paper.

\section{Notes}

[Insert endnotes here]

\section{References}

Abraham J 2009 Metropolitan Lovers. The homosexuality of cities University of Minnesota Press, Minneapolis.

Brown G 2008 Urban (homo)sexualities: ordinary cities, ordinary sexualities Geography Compass 2 (4) $1215-1231$. 
Brown G 2009 Thinking beyond homonormativity: performative explorations of diverse gay economies Environment \& Planning A 411496 - 1510.

Brown G 2012 Homonormativity: a metropolitan concept that denigrates 'ordinary' gay lives Journal of Homosexuality 59 (7) 1065 - 1072.

Bell D 2003 Homosexuals in the heartland: male same-sex desire in the rural United States' in Cloke P ed. Country Visions Pearson, Harlow 178 - 194.

Bell D and Valentine G 1995 Queer Country: Rural lesbian and gay lives Journal of Rural Studies $11113-122$.

Binnie J 1995 Trading Places: Consumption, sexuality and the production of queer space in D Bell and G Valentine eds Mapping Desire: Geographies of Sexualities Routledge, London 182 - 199.

Browne K 2011 Beyond rural idylls: imperfect lesbian utopias at Michigan Womyn's Music Festival Journal of Rural Studies 2713 - 37.

Cloke P and Little J eds 1997 Contested Countryside Cultures: rurality and socio-cultural marginalisation Routledge, London.

Duggan L 2002 The new homonormativity: the sexual politics of neoliberalism in $\mathbf{R}$ Castronovo and DD Nelson eds Materialising Democracy: Towards a Revitalized Cultural Politics Duke University Press, Durham, NC 175 - 194.

Evans N, Morris C and Winter M 2002 Conceptualizing agriculture: a critique of postproductivism as the new orthodoxy Progress in Human Geography 26 (3) 313 - 332.

Fuller D and Jonas AEG 2003 Alternative financial spaces in A Leyshon, R Lee and CC Williams eds Alternative Economic Spaces Sage, London. 55 - 73. 
Gibson-Graham J-K 1996 The End of Capitalism (As We Knew It): A Feminist Critique of Political Economy Blackwell, Oxford.

Gibson-Graham J-K 2005 Surplus possibilities: post-development and community economies Singapore Journal of Tropical Geography 26 (1) 4 - 26.

Gibson-Graham J-K 2006 A Post-Capitalist Politics University of Minnesota Press, Minneapolis, MN.

Gibson-Graham J-K 2008 Diverse economies: Performative practices for 'other worlds' Progress in Human Geography 32(5) 613-632.

Gibson-Graham J-K, Cameron J and Healy S 2013 Take Back the Economy: An ethical guide for transforming our communities University of Minnesota Press, Minneapolis, MN.

Gorman-Murray A 2007 Rethinking queer migration through the body Social and Cultural Geography $8105-21$

Gorman-Murray A 2009 Intimate mobilities: emotional embodiment and queer migration Social and Cultural Geography 10 (4) 441-460.

Gorman-Murray A, Pini B and Bryant L eds 2012 Sexuality, Rurality and Geography Lexington Books, Plymouth.

Gorman-Murray A, Waitt G and Gibson C 2012 Chilling out in cosmopolitan country? Urban/rural hybridity and the construction of Daylesford as a 'lesbian and gay rural idyll' Journal of Rural Studies $2869-79$.

Gritzas G and Kavoulakos K I 2015 Diverse economies and alternative spaces: An overview of approaches and practices European Urban and Regional Studies (early online) $1-18$. 
Halberstam J 2005 In a Queer Time and Place: Transgender Bodies, Subcultural Lives New York University Press, New York City.

Halfacree K 2006 From Dropping out to Leading on? British Counter-Cultural Back-to-theLand in a Changing Rurality Progress in Human Geography 30 (3) 309 - 336.

Halfacree K 2007 Back-to-the-Land in the Twenty-First Century - Making Connections with Rurality Tijdschrift voor Economische en Sociale Geografie 98 (1) 3 - 8.

Halfacree K 2012 Heterolocal Identities? Counter-Urbanisation, Second Homes, and Rural Consumption in the Era of Mobilities Population, Space and Place 18209 - 224.

Hennen P 2004 Fae spirits and gender trouble Journal of Contemporary Ethnography 33 (5) $499-533$.

Herring S 2010 Another Country: Queer Anti-Urbanism New York University Press, New York City.

Jones N 1997 Diverging Voices in a Rural Welsh Community in P Milbourne ed. 1997 Revealing Rural 'Others'. Representation, Power and Identity in the British Countryside London, Pinter. 135 - 146.

Knopp L 1992 Sexuality and the spatial dynamics of capitalism Environment \& Planning D: Society \& Space $10651-669$.

Knopp L 2004 Ontologies of Place, Placelessness and Movement: Queer quests for identity and their impact on contemporary geographic thought Gender, Place and Culture 11 (1) $121-134$.

Knopp L and Brown M 2003 Queer diffusions Environment and Planning D: Society and Space $21409-424$. 
Lee R 2010 Spiders, bees or architects? Imagination and the radical immanence of alternatives/diversity for political economic geographers in D Fuller, AEG Jonas and R Lee eds Interrogating Alterity: Alternative Economic and Political Spaces Farham, Ashgate $273-287$.

Little J 2003 Riding the rural love train: heterosexuality and the rural community Sociologica Ruralis 43 (4) $401-417$.

Marsden T 1998 New Rural Territories: Regulating the Differentiated Rural Spaces Journal of Rural Studies 14 (1) 107 - 117.

Milbourne P ed. 1997 Revealing Rural 'Others'. Representation, Power and Identity in the British Countryside London, Pinter.

Miller D 2010 Anthropology in blue jeans American Ethnologist 37 (3) 415 - 428.

Morgensen S 2009 Arrival at Home: Radical Faerie configurations of sexuality and place GLQ: A Journal of Lesbian and Gay Studies 1567 - 96.

Phillips R Watt D and Shuttleton D eds 2000 De-centring sexualities: politics and representations beyond the metropolis Routledge, London.

Podmore J 2013 Critical commentary: Sexualities landscapes beyond homonormativity Geoforum $49263-267$.

Puar J 2006 Mapping US homonormativities Gender, Place and Culture 13 (1) 67 - 88.

Richardson D 2005 Desiring sameness? The rise of a neoliberal politics of normalization. Antipode $37515-535$.

Robinson L 2007 Gay men and the Left in post-war Britain. How the personal got political Manchester University Press, Manchester.

Rowbotham S 2000 Promise of a Dream. Remembering the Sixties Penguin Books, London. 
Sandilands C 2002 Lesbian separatist communities and the experience of nature: towards a queer ecology Organization \& Environment 15131 - 163.

Scott J 2003 A prostitute's progress: male prostitution in scientific discourse Social Semiotics 13 (2) $179-199$.

Shuttleton D 2000 The queer politics of gay pastoral in R Phillips, D Watts and D Shuttleton eds De-Centring Sexualities: Politics and Representations Beyond the Metropolis, Routledge, London 125 - 146.

Smith D and Holt L 2005 'Lesbian migrants in the gentrified valley' and 'Other' geographies of rural gentrification Journal of Rural Studies 21313 - 322.

Soper K 2008 Alternative Hedonism, Cultural Theory and the Role of Aesthetic Revisioning Cultural Studies 22 (5) $567-587$.

Valentine G 1997 Making space: lesbian separatist communities in the United States in $\mathbf{P}$ Cloke and J Little eds Contested Countryside Cultures: otherness, marginalisation and rurality Routledge, London 109 - 122.

Weeks J 2007 The World We Have Won Routledge, London.

Weiss M 2011 Techniques of Pleasure: BDSM and the circuits of sexuality Duke University Press, Durham, NC.

Weston K 1995 Get thee to a big city: sexual imaginary and the great gay migration $G L Q, 2$ (3) $253-277$.

Wynne-Jones S 2014 'Reading for Difference’ with Payments for Ecosystem Services in Wales Critical Policy Studies 8 (2) 148 - 164.

\section{Notes:}


' Hall-Carpenter Archives (hereafter HCA)/JOURNALS/545A, reproduced in GRAIN Newsletter, issue 27, $1983 / 84$.

ii HCA/EPHEMERA/556, GRAIN Newsletter, issue 25, pg. 1, Jan/Feb 1983.

iii HCA/ JOURNALS/545A, GRAIN Newsletter, issue 27, pg. 3, 1983

iv HCA/JOURNALS/545A, GRAIN Newsletter, issue 30, pg. 2 - 3, 1983/84.

${ }^{\vee}$ HCA/EPHEMERA/556, GRAIN Newsletter, issue 25, pg. 8, Jan/Feb 1983.

vi HCA/EPHEMERA/556, GRAIN Newsletter, issue 25, pg. 8, Jan/Feb 1983.

vii HCA/JOURNALS/545A, GRAIN Newsletter, issue 27, 1983

viii HCA/EPHEMERA/556, GRAIN Newsletter, issue 25, pg. 1-2, Jan/Feb 1983.

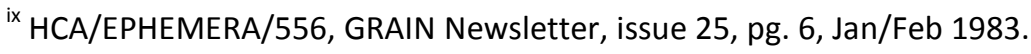

${ }^{x}$ Thanks to one of the anonymous reviewers of this paper who shared this observation with me.

${ }^{x i}$ HCA/JOURNALS/545A, GRAIN newsletter, issue 27, pg. 2, 1983.

xii HCA/JOURNALS/545A, GRAIN newsletter, unnumbered issue, pg. 5-6, Christmas 1985. Letter from Charles Symons, September 1984.

xiii HCA/JOURNALS/545A, GRAIN newsletter, issue 38, pg. 1, Summer 1986.

${ }^{\text {xiv }}$ HCA/JOURNALS/545A, GRAIN newsletter, Winter Issue, pg. 4 - 6, December 1977.

${ }^{x v}$ HCA/JOURNALS/545A, GRAIN newsletter, Winter Issue, pg. 4 - 6, December 1977.

xvi HCA/JOURNALS/545A, GRAIN newsletter, issue 35, pg. 6, September 1985.

xvii HCA/JOURNALS/545A, GRAIN newsletter, issue 27, pg. $16-17,1983$.

xviii HCA/EPHEMERA/556 GRAIN Newsletter, issue 25, pg. 6, Jan/Feb 1983.

${ }^{x i x}$ HCA/JOURNALS/545A, GRAIN Newsletter, issue 30, pg. 2, 1983/84. 